This is the peer reviewed version of the following article: Nuttall, Jeremy (2019) Roy Jenkins and the politics of radical moderation. History, 104(362), pp. 677-709., which has been published in final form at https://doi.org/10.1111/1468-229X.12868. This article may be used for non-commercial purposes in accordance with Wiley Terms and Conditions for Use of SelfArchived Versions. 


\title{
Roy Jenkins and The Politics of Radical Moderation
}

\author{
Jeremy Nuttall
}

Abstract: In light of the frequent contention, amidst Brexit and associated populism, that British politics needs to become both ideologically 'bolder', and better connected with a neglected public, the seemingly archetypally elitist centrist, Roy Jenkins may seem a curiously outmoded subject. This assumption appears shared by historians, who have neglected him. However, this article suggests that if Jenkins was indeed a self-described 'moderate', like many British so-called moderates, he saw that very moderation as underpinning a progressive, and indeed in its way radical vision. In particular, Jenkins argued that by synthesising objectives sometimes seen as conflicting - social equality with individual freedom, the relief of poverty with the fostering of affluence - one achieved more socially transformative outcomes than through pronounced ideological conflict. He illuminates the achievements of this 'radical centre' in British politics, and the unresolved, yet still pertinent dilemmas of the ideological balances it sought. The article also challenges Jenkins' status as the epitome of a disconnected British elite. He had, in fact, much to say about the importance of ordinary people in shaping political and social progress. He was also often sophisticated in perceiving the citizenry's complex mix of progressivism and conservatism, engagement and drift, a mix he displayed himself. Instead, then, of the presently fashionable narrative of elite politicians betraying a virtuous, disillusioned mass, Jenkins' case points to a more connected relationship between leaders and led, in their often shared collection of national vices, yet also virtues. Here, the country's problems, and the means to their solution, then as now, lie in a complex, collective 'us', not in a singular malign 'Other'. 
Roy Jenkins was one of the most important British political figures of the twentieth century. The sheer variety, importance and time span of his contributions is testimony to that: a major intellectual proponent of the Labour revisionism of the 1950s; the main force, as Home Secretary (1965-67), behind the liberalisation of the country's moral code, then a widely acclaimed Chancellor of the Exchequer (1967-70); the leader of the 1971 rebellion of Labour MPs which gave Edward Heath the Commons majority to take Britain into the European Community, and the first British President of the European Commission (1977-81). He was the dominant figure behind the creation of the Social Democratic Party in 1981, and its Alliance with the Liberals, the only serious twentieth-century attempt to 'break the mould' of class politics. Yet, the significance of Jenkins was more than the sum of these diverse parts. He engaged more intensely and enduringly than any other British post-war politician or thinker with the nature of the 'centre ground' in British politics, and its progressive possibilities.

Given this, the scholarly attention to Jenkins remains strikingly limited. John Campbell's impressive biography, published in 2014, has begun to redress this. ${ }^{1}$ There has also been a valuable collection of essays by friends and political allies published shortly after his death in 2003, a comparative work on Jenkins, Tony Crosland and Denis Healey by Labour MP Giles Radice, and, recently, a study of Jenkins as European Commission President. ${ }^{2}$ Yet, the nature of these works, biographical, non-academic, or tightly period-focused, has meant Jenkins' wider significance within post-war British political history, and its accompanying historiographical debate, remains significantly under-scrutinised. The major academic study of the SDP, whilst providing much insight on Jenkins, is so sharply critical of the party's shortcomings that its, and his positive contributions are masked. ${ }^{3}$ Broader studies of Labour 
revisionism, or of progressive thought accord Jenkins an often secondary role, or are dismissive of his perceived lack of egalitarian radicalism. Jackson's otherwise comprehensive study of egalitarian thought, for instance, barely mentions him. ${ }^{4}$ The Jenkins Papers, only deposited at the Bodleian Library in 2011, have also been relatively little used.

The under-scrutiny is especially evident in the context of the considerable historiographical attention paid to two other leading Labour figures, Harold Wilson, the leading political practitioner of Jenkins' era, and Tony Crosland, its most important thinker. ${ }^{5}$ The reasons for this comparative neglect raise some interesting wider points about political historians' predominant focus. The more party loyalist Wilson and Crosland are easier to integrate into party narratives, or intellectual histories of familiar ideological traditions, most commonly egalitarianism. Jenkins' crossing of parties, and fusing of ideologies, introduces an untidy multi-dimensionality, which such studies have too little captured. In addition, partly defining Jenkins' increasing ideological centrism was his belief in a politics which fused intellectual idealism with practical political action. Wilson, whilst acutely intelligent, was above all a political practitioner. Crosland, a systematic thinker, was an at times indecisive politician, largely serving in the Cabinet middle rank. ${ }^{6}$ Jenkins' blend of strategic vision with top level politician defines his importance, yet again renders him less easily historically placed.

This article, then, does not offer a comprehensive narrative history of Jenkins' ministerial record or personal political fortunes, which Campbell's work has already done much to illuminate. Rather, it explores two aspects of what it is argued was his considerable importance within the wider context of twentieth-century British political history. The first concerns Jenkins' distinctive blend of 'radical moderation'. Central to understanding Jenkins is the fact that he saw no contradiction between his 1959 self-description as a politician of 'rather moderate views', and the conclusion of his 1991 memoirs that he was a 'persistent radical'. ${ }^{7}$ Whilst Jenkins' ideas steadily evolved from a mainstream Labour position in the 
later 1940s, through Gaitskellite revisionism in the 1950s and 1960s, to a more explicitly centrist stance by the mid-1970s, this dual commitment to moderation and practicality with a dynamic progressivism remained the defining constant in his position. He saw the moderation and the radicalism as mutually dependent: by focusing constructively on achievable, and well thought out ideas for change, one maximised the chance of progressive outcomes.

Central to this outlook was a belief in the synthesising of approaches or values others, further right or left, might see as conflicting. If this search for synthesised 'third ways' has been a recurring feature of much thinking on the centre of British politics, Jenkins, even by this standard, was distinctive in the range and intensity of his ideologically reconciling instincts: social justice and individual freedom; the relief of poverty and the pursuit of affluence; an interventionist state, but also political and economic decentralisation; a greater societal emphasis on pleasure and leisure alongside a moral sense of social responsibility; direct engagement with political practicality, whilst not losing a sense of long-term vision. Other advocates of middle ways often stood clearly within a single ideological tradition. Harold Macmillan, whilst advocating The Middle Way (1938) was still demonstrably a Conservative, and could be disparaging of the state. Crosland, for all his revisionism, was a strong Labour loyalist, and emphatic socialist. Jenkins was a more cross-ideological, and in that sense less inhibited synthesiser. He was more overt than others on the Labour right about his support for meritocracy and differentials, but less squeamish than Liberals and Conservatives about an active state. Consequently, he arguably came closer to a genuinely measured middle path than most, and he explored the notion and language of the ideological and political 'balance' more than any other leading twentieth-century British politician or thinker. But this was not a static or conservative balance. He believed that in the synthesis lay the radicalism: that in the very fusion of different values lay the creation of something progressively dynamic. 
In important ways, the relative historiographical neglect of Jenkins symbolises a wider under-examination of that ideological and political terrain between left and right in twentiethcentury British history. ${ }^{8}$ The tendency for political narratives to be written within a single party framework, and for intellectual histories to chart the evolution of the 'core' ideas of those parties, whether egalitarian or Conservative, has resulted in an under-playing of the ideological variety and layers within politicians' identities. In particular, the 'centre' component in the thinking of centre-left or centre-right figures, and the attachment to ideological inclusivity which often came with that, whilst acknowledged, has been less systematically examined than the adjoining left or right element, and the degree of fidelity to a 'core' left or right value. Whilst work on social democratic thought, for instance, charts the way in which ideas of equality interacted with those of individual freedom, or the pursuit of personal affluence, the primary focus has been on the extent of the thinker's fidelity to the perceived 'core' value of equality. ${ }^{9}$ In this sense, the study of ideological 'depth' is privileged over ideological 'breadth'. The problem is compounded by how, as Michael Freeden notes, the early-century decline of the Liberal Party has obscured the extent of its subsequent moderating intellectual influence well beyond its borders. ${ }^{10}$

If the concept of a moderating centre has been under-scrutinised, so too has been the political moderate's perhaps surprisingly persistent claim not merely to serve a stabilising, socially unifying function, but to offer an imaginative progressive vision. Brian Harrison, for instance, suggests that 'centrists lack ... sparkle, brilliance, originality, colour, and imagination'. ${ }^{11}$ Jenkins is amongst the strongest evidence against this. But many others on the British centre-left or centre-right have been passionate in their insistence that their beliefs were no less creative or transformative than those further to their right or left; indeed they thought them to be more so. For author of The Middle Way (1938), Conservative Harold Macmillan, in 1957, now Prime Minister, whilst his belief in 'one nation' was 'not doctrinaire ... [but one 
of] common sense', that 'does not mean that we do not have strong principles'. ${ }^{12}$ Similarly, the young Labour revisionist, Evan Durbin, whom Jenkins admired, insistently described himself in 1937 as a 'militant Moderate'. ${ }^{13}$

An exemplar of the centre's and centre-left's capacity for ideological dynamism, Jenkins also illustrates its persistent political influence. True to his fusion of ideas with action, he saw his progressive vision as one rooted in evolving practical actuality, not simply distant possibilities. His memoir, A Life At The Centre was a reference to ideological positioning, but also a claim to direct political impact. ${ }^{14}$ If his role at the heart of the 1964-70 government shows this most directly, his contributions in the 1970s and 1980s, on Europe, but also to Labour and Alliance politics suggest a moderate progressive tradition more resiliently influential, even if at times defensively so, than uniformly declinist accounts of social democracy in these years suggest. This chimes with research increasingly suggesting that contemporary British political eras have often been more pluralist, less hegemonically 'right' or 'left' than supposed, even under the apparently ascendant Thatcherism. As Andrew Hindmoor has recently demonstrated, political and social progress did not simply end in 1970, or $1979 .{ }^{15}$

Though, Jenkins is also illustrative of unresolved progressive dilemmas. His consistent critique of class politics resulted in frequent frustration at its endurance, culminating in the foundering of his SDP, as he saw it, on 'the resilience, behind the fortifications of the British electoral system, of the Conservative/ Labour duopoly'. ${ }^{16}$ But Jenkins also showcases the centre-left's internal intellectual shortcomings. As Stephen Meredith observes, by the 1970s, 'as the adhesive ideological framework of Keynesian social democracy ... collapsed around them, the Labour right had the fundamental problem that they didn't have anything to say'. ${ }^{17}$ Jenkins still, in fact, had much to say. But from the late 1960 s on, his thinking had a 'notes towards' characteristic, with progressive dilemmas identified, yet not fully resolved, in 
a way which represents the wider transitional uncertainty of the British social democratic and progressive tradition between the mid-1960s reforming heyday of the Wilson government, and the emergence of New Labour in the mid-1990s.

Two shortcomings stand out. Firstly, as Chancellor from 1967, whilst highly successful in overcoming the most pressing economic crisis, that of the balance of payments deficit, Jenkins shared in the wider government's drift into a largely defensive agenda of economic stability, and lacked the imagination and will to set out an optimistic vision of what an enabling state might offer next. Secondly, Lawrence Black has written of progressives' persistently uneasy relationship with the social and cultural changes emanating from post-war 'affluence'. ${ }^{18}$ Jenkins did more than most to seek to address this problem. But he remained too conventionally top-down a social democrat fully to succeed in this, and as SDP leader in the early 1980 s did not sufficiently understand the heightened contemporary appetite for social mobility, and for greater choice and accountability in public service provision.

Yet, Jenkins was fundamentally a political optimist, and this optimism was founded in important part on his nuanced, but fundamentally positive view of the active political role of the people, the second subject of the article. The relationship between 'elites' and people has received considerable historiographical attention, which broadly advances two perspectives. The first points to elite neglect and dismissiveness of 'the people', most systematically articulated through John Carey's influential depiction of an early twentieth-century British intellectual and literary class divorced from, and dismissive of the emerging twentieth-century democracy. ${ }^{19}$ Particular emphasis has been placed on the supposedly top-down, technocratic nature of the 'consensus' politics between the 1940s and 1970s, which housed much of Jenkins' political career. ${ }^{20}$ Historians like Black and Jarvis have relatedly shown how the subject of emerging societal 'affluence' in these years revealed alarm and condescension on right and left alike as to the impact of individualism or materialism on the populace's moral, socialist or 
religious fibre. ${ }^{21}$ This chimes with analysis of later, contemporary political populism by Eatwell and Goodwin, positing this populism as a reaction against elite centralisation of power: 'liberal democracy always sought to minimize the participation of the masses'.22

Jenkins' case certainly provides support for elements of this critique. He frequently evidenced a strain of Whiggish, paternalist elitism. Historians have focused on this dimension of him, a 'patrician', 'the archetype of the "Eurocrat", his Jenkinsite grouping displaying an 'air of ineffable superiority'. ${ }^{23}$ Even Jenkins' close political admirer, David Marquand wrote of him that 'he owed his reputation to glittering performances in the introverted villages of Westminster and Whitehall'. ${ }^{24}$ His memoirs read as a fascinating chronicle of the inter-play of leading personalities and issues, but contain strikingly little on the broader sweep of social change. He too exclusively saw the pursuit of progressivism in terms of dramatic high political moments, of 'influence on the course of events'. ${ }^{25}$ In these ways, Jenkins casts light, to draw on Peter Clarke's terminology, on the problems of an overly 'mechanical' post-war politics.. ${ }^{26}$

Secondly, Jenkins' example, in different ways, also provides support for the in some respects countervailing arguments of the 'constraints' school of political history, pursued notably by Steven Fielding, which cautions against either romanticising the people or demonising the politicians leading them. Specifically, the voters were not always as intrinsically collectivist, liberal-minded, or politically engaged, as politicians, especially progressive ones, might have wished them to be, and thus, in accounting for the relatively shortlived nature of the reforming Labour governments of the 1940s and 1960s, the people might be adjudged as much 'in the dock' as their leaders. ${ }^{27}$ Jenkins, a persistent realist, was, for a progressive politician, more than usually alive to the conservative strains in the electorate, to how, as Black has explored in relation to the supposedly 'radical' 1960s, politics then was 'more parochial and less dramatic' than often thought, and 'not automatically progressive'. ${ }^{28}$ 
There is, however, a third, less explored dimension to the relationship between politicians and citizenry, which exhibits more common ground in the outlooks of the two, outlooks which could often be constructive or progressive, not merely conservative. This rested in part, to return to Clarke's terms, on the under-estimated persistence of a 'moral', not merely 'mechanical' politics through the twentieth-century, in which both the values and the active political engagement of the people were seen by politicians to be essential to political and social progress, which could not be achieved in a purely top-down fashion. A growing body of work is charting the importance of character, mind-set and values to both the century's political visions, and the methods of achieving them. Politics rested on psychology as much as economics or institutional structures. ${ }^{29}$ Given that Jenkins is often seen as the archetype of elitist, paternalist 'mechanical' politics, that he in fact held a co-existing, and in some ways ultimately stronger belief in 'moral politics' is of considerable significance. He repeatedly articulated his philosophy as one of ideals and ethics, explicitly warned of the dangers of both an over-focus on economics, and a drift into managerialist pragmatism, and saw political leadership very much in terms of strength of character.

This moral politics shaped Jenkins' approach towards 'the people', which was more complex, interesting and important than the one-dimensionally elitist portrait captures. He believed both that politics was fundamentally determined by the values of the people themselves, and that it should serve their needs and ambitions. This led him to emphasise, especially within a Labour Party context, the importance of being in touch with the voters. It also underpinned his consistent commitment to political and economic decentralisation and democratisation, and his belief that, through prioritising education, culture and social liberalisation, politicians should pursue an agenda which liberated minds and emotions, not simply fine-tuned the economy. Underpinning it all was a firm liberal enlightenment optimism in a certain under-estimated 'decency' in the people. 
Above all, Jenkins, reflecting his ideologically 'middle' position, was distinctive in the extent to which he captured a sense of the British people as a complex mix, as both progressive and conservative, at times engaged, at times apathetic, marked by both vices and virtues. In many ways, he saw his own mixed ideology and character in them. Jenkins' perspective offers support for Jon Lawrence's argument that in assessing the shift from a more boisterous, masculine and outdoor Victorian politics, to an in some ways more domesticated, 'low-key and homely' one over the twentieth century, the continued vibrancy, engagement and 'quiet' reflectiveness of the latter can be too easily under-estimated. People's deliberative “"peaceable-ness", Lawrence notes, "was not the same as passivity'. ${ }^{30}$ Jenkins saw the voters as adaptive, and frequently capable of a more constructively progressive political role than might be assumed of them. To the extent, then, that Jenkins was an archetype of the historical British middle way 'elite', his example suggests grounds for caution in asserting that these 'moderate' elites who have so shaped modern British political history should be viewed as straightforwardly disconnected from the citizenry they were supposed to serve. The people, after all, frequently voted for such figures. Here, perhaps, lies a historical narrative less of repeated elite 'betrayal' of the people, and more of politicians and people pluralistically intertwining in that mix of evolving strengths and weaknesses they shared.

\section{II}

Roy Jenkins first became a Labour MP in 1948. His loss of his SDP seat in 1987 marked the end of his front-line political career. During these thirty-nine years, whilst his ideas evolved, and his party allegiance eventually altered, his belief in a progressively dynamic middle way politics, built around creative ideological syntheses, was a uniting constant. In this, he was partly a reflection of his times. The claim to a British middle way was articulated with 
particular conviction in Jenkins' politically formative years, the 1940s and 1950s, which seemed, after the manifest imbalances of inter-war mass unemployment and still relatively laissez-faire government, to have achieved a happy synthesis of a welfare state with, by the end of the 1950 s, new consumer affluence. This was a notably optimistic political era, assuming progress through the synthesised golden mean. 'The British economy is most unlikely, in any long-term sense to relapse into uncontrolled capitalism', wrote Jenkins confidently in $1953 .{ }^{31}$ Conservative Prime Minister, Harold Macmillan laid claim in 1957 to an approach to governance built on 'balance and proportion'. ${ }^{32}$ Jenkins' then close friend and ideological soulmate, Tony Crosland's The Future of Socialism (1956) described a future with social equality, democracy and individual freedom advancing in mutual harmony. ${ }^{33}$

Yet, even by the standard of the above two figures, who would remain firmly within their respective parties and accompanying ideological traditions, Jenkins' interest in notions of political synthesis, and in where lay the 'middle', was especially marked. Here, the influence of his times blended with his own mix of personal influences. For all the later mockery of Jenkins for his social grandeur, these were impeccably working class. He was born in Abersychan in South Wales, the son of a miner, Arthur Jenkins, who was imprisoned during the 1926 General Strike. But Arthur was also the epitome of social mobility, rising into the emerging aristocracy of the labour movement, as a union official, PPS to Clement Attlee and eventually a minister in the 1945 Labour government. The early roots of Roy's enthusiasm for Europe can also be seen in what was a Francophile household. There were childhood trips to France and Belgium, and Arthur spent nearly a year in Paris, developing good connections with the French left-wing. ${ }^{34}$ Reaffirming Arthur's keen mind and social mobility, the grammar school-educated Roy secured First Class Honours in PPE at Balliol College, Oxford, before becoming Labour MP for Central Southwark at a 1948 by-election, and subsequently, from 1950 until his temporary departure from British politics in 1976, for Stechford, Birmingham. 
Jenkins thus imbibed a characteristically double worldview, shaped by a mix of modest and elevated social environments. 'I have been lucky enough to receive a good education', he told the Stechford selection meeting in 1950. But 'I certainly wasn't brought up in luxury, and during my early years the shadow of poverty was never very far away from my home, as from that of our neighbours; and one doesn't forget these things'.35

Jenkins' background shaped a lifelong belief in the possibility of joining a commitment to eroding poverty with the encouragement of individual freedom and aspiration. His political vision was almost always emphatically multiple, not singular. In the debates in the 1950 s over Labour's next steps following the implementation of much of its existing socialist programme in 1945-51, he supported the revisionist position led by (from 1955) party leader Hugh Gaitskell. Rejecting equally Herbert Morrison's pragmatic advocacy of 'consolidation', and the Bevanite left's focus on further nationalisation, Jenkins argued for simultaneous promotion of a trio of values to which he was to remain attached: social equality, individual freedom and (a persistent Jenkins' ideal), democratic participation. These, he believed would merge an egalitarian zeal, built around Keynesian economic management, selective public ownership, redistribution, and educational opportunity, with a recognition of a changing, more affluent society, and the need for incentives. No less important would be the encouragement of a more involved citizenry and workforce than the top-down 1945 settlement had permitted. 'The three key objectives of future socialist programmes', he wrote in his early book, Pursuit of Progress (1953) 'should ... be more equality, more democracy, and more freedom. ... [T]he three objectives will act and interact upon each other; and in general ... measures designed primarily towards the achievement of one of the objectives will incidentally help the others. ${ }^{36}$ The Labour revisionists were seeking to promote greater equality, in a way that was, as Ben Jackson notes, 'far more expansive' than that implied by a merely legalistic equality of opportunity. ${ }^{37}$ In his essay on 'Equality' in the early work of socialist re-thinking, New Fabian Essays (1952), 
Jenkins wrote of equal opportunity that 'there would be certain dangers in concentrating too much attention upon it without ensuring that it was accompanied by other egalitarian measures' ${ }^{38}$ Yet, they, and especially Jenkins, were also sensitive to an accompanying need for differentials, on meritocratic grounds, for instance: 'payment for time spent in acquiring special knowledge and skills there must continue to be'. ${ }^{39}$

Linked to this was a desire to synthesise working- and middle-class interests. As early as 1945 , before the general election, and aged only twenty-four, Jenkins told an audience in Banbury that 'to make itself the majority govt. of the country it [Labour] must win the support of new areas and new social groups. Banbury should be every bit as important as is the Rhondda Valley.' ${ }^{40}$ Reflecting in 1956, he argued that 'the British socialist tradition has always been primarily concerned with people as individuals and not as abstractions or constituents of a particular class'. ${ }^{41}$ By the later 1950s, that mix of extended state welfare and consumer prosperity appeared to confirm the erosion of poverty and the advancement of affluence as bedfellows, not alternative choices. In his The Labour Case (1959), published before the election, Jenkins characteristically articulated the political challenge as a double one, 'to attempt both tasks at once: to destroy the islands of acute poverty which still disfigure our society, and at the same time to offer a continuing improvement to those who have already attained average prosperity.' As so often in politics, he noted, the need was 'to strike a balance' ${ }^{42}$

A third synthesis, underlying the other two, was that between idealism and practicality. Whilst he had studied PPE, Jenkins' primary intellectual interest was as a biographical historian, beginning with his short 1948 study of Attlee. Lacking Crosland's more sociological and theoretical ability to survey the broad sweep of contemporary trends, Jenkins' historical perspective gave him more sense of the lived-out inter-play between hopes and actuality. It was important, he believed, to pursue policy with 'regard to historical continuity or to the 
organic relationships of society'. ${ }^{43}$ This made him a critic of what he saw as his party's at times oppositionist mentality, making a hazily posited best the enemy of the good. Increasingly, as he made clear in a 1952 broadcast, Jenkins perceived this in Bevanism, which was 'suggesting that emotional attitudes are more important than policies, ... and that pleasant slogans solve unpleasant problems' ${ }^{44}$

Yet, he was no less conscious that there was an opposite danger, that this pragmatism could lapse, even within the Labour Party, into an over-satisfaction with the status quo. The country therefore needed 'a programme to fit the needs of 1953 which is at once as radical and as practical as that of $1945^{\prime} .{ }^{45}$ He rejected with some passion the charge that 'moderates' in the party were less caring, progressive, or rooted in the real lives of communities than those supposedly more 'left wing'. Past Labour moderates, he suggested in 1953, included local authority leaders and trade unionists who were 'deeply sensible of the human suffering amongst which they lived, and were unwilling to sacrifice for doctrinal reasons the possibility of doing something to alleviate it' ${ }^{46}$ Jenkins would repeatedly emphasise his restless 'radicalism' and 'idealism'. Criticising, in the aftermath of Labour's 1959 election defeat, what he saw as the left's obsession with nationalisation, he warned that 'by being cluttered up with dogma, which in fact you don't advance very courageously or vigorously, you reduce your cutting edge, not increase it' ${ }^{47}$ 'Moderation', he would later reflect, must not be 'a euphemism for compromise, for muddle'. Rather, 'politics - the politics of moderation if you like - should be extremely sharp, and should be extremely clear-cut, and ... radical purposes can be accomplished often more successfully by those who believe in moderation'. ${ }^{48}$

This was a definition of radicalism different from 'left', as conventionally understood. The key concept in delineating this is 'constructive'. For Jenkins, constructiveness entailed seizing the real world opportunities for social improvement at a given moment, and was distinguished, as he saw it, from both a rigid Conservatism which under-estimated those 
opportunities, and a left position which exaggerated them. Jenkins used the word frequently throughout his career, rejecting the view 'that oratory is a better test of socialism than is constructive achievement'. ${ }^{49}$ It informed his laudation of Liberal Prime Minister Herbert Asquith, the subject of Jenkins' most original biography, published as he was about to enter government in 1964, and a model for his own governing style. Gauging precisely the moment of progressive opportunity - moving neither too early, nor too late - "“a sudden curve developed itself of which I took immediate advantage"” - was, Jenkins approvingly wrote, Asquith's characteristic approach. ${ }^{50}$ 'Constructive' also later encapsulated Jenkins' claim as SDP leader to offer a cross-class politics to rise above dogmatic divides, and provide 'imaginative and constructive statesmanship'. 51

This claimed constructiveness was as much a political psychology, as an ideology. As much as any specific policy, Jenkins believed, Labour needed to exhibit the outlooks of nonclass sectionalism, perspective, and openness to new thoughts. Favouring 'the non-cataclysmic approach to Socialism', he wrote in 1952, Labour must be 'a reforming party which remains open-minded and undazzled by its own success'. ${ }^{52}$ These were attributes which were to underpin Jenkins' appeal to many parliamentary colleagues, resulting in his attraction of a loyal Jenkinsite faction on the intellectual right of the party (a cabal, critics felt) from the mid-1960s. Followers admired, one of them, Shirley Williams noted, 'his willingness to discuss, to be open to question, to carefully reconsider his own position'. ${ }^{53}$ Jenkins also went to great lengths, with sometimes comically mathematical routine, to ensure his life balanced intense political activity with a cultural hinterland of plentiful social lunches, writing, and sleep. This, he believed, brought that crucial 'proportion' to his political decision-making. Politics was best 'not always taken in excessive doses'; it should not be the preserve of the obsessive. ${ }^{54}$

This emphasis on the importance of mentality reflected Jenkins' wider belief in the need for a 'moral', not merely technocratic politics. This shaped his and the other Gaitskellites' 
understanding of the concept of equality, which they defined as being as much about the cultivation of a less deferential, status-ridden mood in society as more material redistribution. 'Economic policies, measures of nationalisation; these are only the means to an end', Jenkins insisted in 1950. 'The end is the creation of a society in which everybody can live full, contented and worthwhile lives, working in a decent atmosphere, and living in good houses \& pleasant surroundings. This is the end, and we must never lose sight of it. ${ }^{55}$ This also entailed a higher political priority for leisure, culture and free decision-making in private life. Echoing Crosland's famous call at the end of The Future of Socialism for a leisured vision of 'more open-air cafes, brighter and gayer streets at night', Jenkins described in 1959 a future of 'better buildings and better food, of better music (jazz as well as Bach) and better books, of fuller lives and greater freedom'. ${ }^{56}$

The most tangible policy area for this agenda of empowering minds was education, and like Crosland and Gaitskell, Jenkins accorded it particular importance: 'Education should ... be given a leading place in the social service queue. ${ }^{57}$ Though the issue also illustrated Crosland's and Jenkins' ideological differences, which were to become increasingly marked by the 1970s. Jenkins was more wedded than the comprehensive school-promoting Crosland to the meritocratic ethos of the grammar schools from which he had personally benefited. 'There are many who dislike levelling-down in any form', he wrote in 1953. 'But it is far more justifiable in the case of material rewards, where it can be argued that great wealth is in itself socially undesirable, than in the case of education, where it certainly cannot be argued that the highest standards are not in themselves of great value. ${ }^{58}$ Jenkins favoured an organic approach, reflecting the diverse preferences of individual localities, and saw the main route to expanding opportunities as lying in 'the devotion of more resources to education', not uniform structural change. ${ }^{59}$ 
Central to Jenkins' conception of a moral politics, and contrary to the frequent portrayal of him as merely the archetype of a middle century era of elitist political paternalism, was a belief in the critical importance of 'the people' in shaping the extent of political and social progress. Dovetailing with his belief in political 'balance', Jenkins held a subtle, mixed view of the British public. On the one hand, he was notably alive to the power of conservative outlooks, less of a Panglossian optimist than Crosland: 'excessive optimism in politics is as likely to be misplaced as excessive pessimism'. ${ }^{60}$ Reflecting in 1953 on 'the essential strength of Conservatism', he noted that this lay above all in its persistence and appeal less as 'the defence of a particular set of institutions or class interests', which might become redundant, and more as the enduring 'expression of an attitude of mind'. ${ }^{61}$ He would therefore 'get tired of people who talk as though people straining at [the] back for [an] advance to socialism \& only reactionary leaders holding them back', ${ }^{62}$

Yet, this worldly realism, and greater appreciation than most Labour politicians of Conservatism's appeal, was joined by a persistent optimism about the people, one all the more noteworthy for its co-existing groundedness. Jenkins believed that both Conservatives, and, in a different way, some on the left failed to perceive a quiet, earthy good sense in the people, which whilst short of persistent radicalism, mixed frequent politically 'forward' constructiveness, with notable radical bursts. Fortified by the wide public support for Labour's programme in 1945, Jenkins could assert by the eve of the 1951 election that the Conservatives 'underestimate [the] electorate'. ${ }^{63}$ 'We are proud of the work of the British people', he reflected in his 'Eve of Poll' notes of 1950. 'We regard the old myth that social security and full employment would sap the workers' will to work as having been decisively disproved. ${ }^{64}$ By the harder economic times of the later 1960s, as Chancellor, this underlying faith would endure: 'if the British people were told the hard facts of our economic situation, ..., then for their part they would be willing - indeed, anxious - to make the sacrifices'. ${ }^{65}$ 'People', he later 
affirmed, 'are often more perceptive than some politicians realise'. ${ }^{6}$ Contrary to depictions of a British elite uniformly negative in their perception of the masses under the democracy established in 1918, Jenkins' outlook reinforces Dan Le Mahieu's charting of more common ground understanding between rulers and ruled, notably via figures like J.B. Priestley and George Orwell, who articulated a middlebrow 'English Everyman' taste, in which the people seemed possessive of an under-estimated, albeit imperfect 'decency' ${ }^{67}$

It was also, Jenkins insisted, a decency more robust than was evident in those contemporary critiques, common on both right and left, of a population seduced by the gloss and selfishness of material affluence. Jenkins' high valuation of a sense of historical and political perspective and proportion made him consistently sceptical of most articulations of popular moral 'declinism', noting in 1959 , that 'the satisfaction of wants is at least as likely to free people's thoughts from material things as to concentrate them there'. ${ }^{68}$ 'Non-attendance at [political] meetings [is] not necessarily a sign of moral degeneration' ${ }^{69}$

What was certain, Jenkins adjudged, was that in an organic, democratic society, the people were not mere bystanders, but to an underestimated extent themselves shapers of the very national character, and through that the country's politics. 'Governments', he believed, 'are to a large extent the servants and not the masters of the nation' ${ }^{70}$ Hence, this supposed epitome of elitism explicitly rejected 'the principle expressed in a much quoted phrase of [fellow Gaitskellite] Mr Douglas Jay [in 1937] that "the gentleman in Whitehall really does know better what is good for people than the people know themselves"'. "The only certainty about the result', Jenkins cautioned, 'is that most of the decisions would be wrong'. ${ }^{71}$

This belief in the importance of the people's role was not, though, an invitation to either crude populism, or decision-making by opinion poll. The approach, he later asserted, amidst the Wilson government's mounting unpopularity by 1967 , should be 'not to be indifferent to public opinion, yet to keep our course firm'. ${ }^{72}$ He was to be nervous of the forces that might 
be unleashed by a referendum on the Common Market, and would resign, in 1972, over Wilson's promise of one. 'I think that this has got to be a once for all referendum', he opined in 1975. 'I believe in democracy, but I also believe in leadership. ... I think what politicians should say: "These are my opinions, you don't like them, change me"., 73

Jenkins' arguably sophisticated view of the people merits more consideration as a middle position within historiographical debates over whether the twentieth-century British electorate was progressive or conservative, engaged or apathetic. ${ }^{74}$ Reflecting the multiplicity of his own ideological makeup, Jenkins observed that ideological conflict 'is not only between individuals. It is often within individuals themselves, one set of their desires and beliefs stemming from a quite different tradition and philosophy from another'. ${ }^{75}$ This complex mix also defines Jenkins' place in the history of British social class outlooks. With partial justification, his critics repeatedly pointed to his grand manner, frequenting of elite London gentleman's clubs, like Brooks's, and extra-marital affairs with aristocratic or well-connected women such as Caroline Gilmour and Leslie Bonham Carter, as contradictory with his own firm advocacy of a classless social 'spirit'. Fellow Labour intellectual Richard Crossman thought Jenkins 'a reserved, aloof man', with 'a patrician air, .. disdainful, detached'. ${ }^{76}$ Young fellow revisionist, David Owen recalls how Jenkins' 'all-male London clubs got up my nose', and how, on one occasion, 'I was summoned to his hotel as if he were a headmaster hauling in an errant schoolboy'. ${ }^{77}$ More theoretically, Jenkins would also later reflect on the benefits of establishment institutions as a counterweight to Thatcherite individualism: the House of Lords 'joins with the ancient universities, the established Church and, indeed, the monarchy in providing a few islands of countervailing liberal urbanity in a sea of brashly selfish materialism with little sense of continuity'. ${ }^{78}$ If there was insight in the general point, his institutional choices were notably and conventionally narrow. 
Yet, there was another side. For one, given Jenkins' modest class background, what snobbery he displayed was less that of the secure establishment man than, as David Marquand notes, the 'Welsh arriviste', a man masking a notable inner shyness. ${ }^{79}$ His grandeur co-existed with an 'engaging form of self-deprecation', a firm openness to absurdity and self-criticism, repeatedly evident in his highly regarded memoirs, an attentiveness to his political colleagues, and a striking assiduousness in replying to correspondence from the public or interested researchers. ${ }^{80}$ By no means a hands-on constituency MP, nor, on the whole, an enthusiast for public campaigns, he was, however, notably respected by the public, especially the 'floating voter', for his competence and independence. ${ }^{81}$ 'Never once', observers noted, 'did he patronize his audience by talking down to them'. ${ }^{82}$ David Cannadine captures the persistent duality in which British politicians were both defined by class, and determined to rise above its starker divides, 'transcending the division of society, even as in other ways they embodied it' ${ }^{83}$ This was notably true of Jenkins, whose elitist and social democratic instincts sat alongside one another. Through this complex, contradictory but always authentic mixture, he was, as in other ways, a figure more representative, and revealing of the many-sidedness of the people he served than is captured by the image of the remote grandee.

\section{III}

Jenkins was one of the most important figures in the 1964-70 Labour government. At times, he was its most decisive and dynamic one, presiding as Home Secretary over one of the government's major legacies, the liberalisation of the country's legal framework on personal morality, and then, as Chancellor, finally resolving the decade's most destabilising economic problem, the balance of payments deficit. These years were to constitute the high point of his governmental influence. By the late 1960s, he was widely seen as the Cabinet star, the 
Chancellor whose economic success seemed the most likely route to Labour securing reelection, and Wilson's most probable successor. Jenkins was critical of both the strategic direction and governing style of Wilson in ways which would intensify in the 1970s. But he also thought the administration's record overall a creditable one, which its later critics (including internal party ones) self-servingly under-acknowledged. The government had 'mingled ... competence with compassion' ${ }^{84}$

It was another of Jenkins' syntheses, the marrying of the attributes of the thinker with the politician, which lay at the heart of his, and in important parts the government's success. It is often remarked that this government contained a strikingly high number of such cerebral practitioners, but Jenkins was distinguished by his genuinely equal fusion of the attributes. He had a stronger sense of intellectual direction than Wilson. Jenkins became more admiring of Wilson's adept political management, but like many critics, saw him as 'a tricky fellow', 'bereft of any strategic framework' ${ }^{85}$ This criticism of approach was also crucial to his major policy critique of the government, the failure to devalue earlier, culminating in the forced devaluation in 1967. Here, Jenkins believed, economic orthodoxy had combined with a lingering overestimation of Britain's global power: ‘the rate of $\$ 2.80$ was clung to as a symbol of national pride'. ${ }^{86}$

If Jenkins thought Wilson short on vision, he felt the intellectual Crosland, now increasingly falling behind Jenkins as the recognised leader of the revisionist right, lacked practical political attributes. Crosland was 'cleverer than I was', Jenkins generously acknowledged, but he lacked the latter's tough-minded political decisiveness. 'The disadvantage of Crosland's impressively ratiocinative progress towards a view', noted Jenkins, 'was that when the three days had gone by and he had come out of the dark the issue had often resolved itself'. ${ }^{87}$ Amongst Jenkins' other senior colleagues, if Callaghan replicated Wilson's managerialist excesses, Crossman shared the intellectual Crosland's lack of focus, and George 
Brown was personally volatile. As a minister, Jenkins, to a unique extent, combined a strong sense of intellectual reforming purpose with focused decision-making, mastery of detail and strong Commons' performances. No natural ideological ally, the left-wing Crossman admired Jenkins' 'political willpower': 'when he's taken a decision he sticks to it through thick and thin' ${ }^{88}$

One of the most impactful Home Secretaries (1965-67) of the century, Jenkins made government time to push through Private Members' Bills on homosexuality and abortion, began the ending of theatre censorship and corporal punishment in prisons, and introduced what was to become the 1968 Race Relations Act. Less well known, this liberalism was accompanied, during what was a marked crime wave, by the 1967 Criminal Justice Act, introducing majority verdicts in jury trials, and streamlining committal proceedings. Here, Jenkins believed, was balanced politics in action: 'I have never seen the slightest contradiction between being tough where we need to be tough, and striving at the same time to enlarge the area of human freedom'. ${ }^{89}$

Though, his time as Home Secretary also highlighted enduring dilemmas. Jenkins' general instinct to 'trust the people' was always qualified by the recognition that some issues, including several of the above, were likely to showcase a parliamentary elite more 'liberal' in outlook than the general public. This again highlighted his 'moral politics', a recognition than mere legal change was not sufficient in itself to transform underlying societal values. Reflecting, in 1967, on the issue of progress towards more egalitarian attitudes on race, Jenkins lamented that 'we cannot, as we are often reminded, change men's minds and men's hearts by legislation'. Yet, 'mechanical', legislative change could help ignite a slow-burning fuse of 'moral' change, and a liberal 'elite', in these areas, could and should lead: 'the correct legislative framework can make it much more difficult for ... men's hearts to move in the wrong direction'. 90 
Wilson, who was good at recognising talent, as well as having an instinct for the success of his government, selected Jenkins to replace Callaghan as Chancellor, following the 1967 devaluation. Jenkins was now faced with the urgent need to tackle a balance of payments deficit which had bedevilled the government since its inception. In order to make use of the pound's lower level to drive up exports and squeeze consumption, and after some initial months of hesitancy, he pursued a determinedly tough-minded deflationary policy, most notably in his first, 1968 budget. But he again consciously adopted a progressive-minded balance, mixing tax rises on the wealthy, including a one-off 'special charge' on unearned incomes, with spending cuts. Balance was also sought within the spending cuts, blending the return of prescription charges and a postponement of the raising of the school leaving age, with a more rapid defence withdrawal 'east of Suez', which was also intellectually consistent with his favouring of a more Euro-centric British outlook. It was Jenkins'strategic sense as Chancellor which most impressed David Owen: 'he started by analysing the long-term objectives and then putting together the individual expenditure savings, within the long-term framework. It was an approach which the Government hitherto had so singularly lacked.' ${ }^{91}$ These measures helped to produce a 1969 balance of payments surplus, and turn around the government's lamentable poll ratings. Wilson, too, praised Jenkins' 'firmness and determination' in pursuing his post-devaluation 'balanced package' ${ }^{92}$

In managing to be both, as he put it a 'soft-hearted' Home Secretary and a necessarily 'hard-hearted' Chancellor, Jenkins had shown the very political multi-dimensionality he had long advocated. In each case, he saw himself as addressing the greatest social or economic imbalance of the moment: 'I do not ... in any way regard the attitude I took as Home Secretary as being contradictory with that which I have pursued as Chancellor' ${ }^{93}$ Jenkins had done more than anyone to further his aim of helping Labour 'to prove our competence as a Party of economic management' ${ }^{94}$ 
Yet, his Treasury years also began to pinpoint some of his limitations. As Jenkins was never to have the opportunity to be an expansive, 'good times' Chancellor, or even a 'normal times' one, he must be judged in the exacting environment of these notably difficult years. Whilst he certainly countered the worst excesses of 'in-house' Treasury orthodoxy, there was, by the end, an over-fixation on financial 'restraint'. His repeatedly austere language of 'extremely hard policies', the need for 'hard facts', and the overriding prioritisation of 'a determination to secure stability', hinted at the over-zealousness of the convert. Labour revisionists, from Ramsay MacDonald through Jenkins to, later, Tony Blair, in their laudable eagerness to show the lesson learned that the left must exhibit economic prudence, may have been prone to take the message too far.. ${ }^{95}$ As fellow Cabinet minister, Barbara Castle charged, after Jenkins' proclaimed 'two years hard slog', 'our supporters in the country would have been glad of a bit more populist vulgarity [social spending]' from Jenkins' 1970 pre-election budget, which was, Jenkins himself later admitted, 'more restrictive than perfect economic foresight would have made it' ${ }^{96}$ The overriding focus on the balance of payments problem also made for a one-dimensionality - 'I have had to concentrate on dealing with this single ... issue' that was inimical to his oft-stated attachment to breadth and multiplicity of vision. ${ }^{97}$

If this showed the power of the pressure of events to shift even the insistently reflective Jenkins' ministerial style into one of crisis management mode, it also indicated a more underlying loss of social democratic direction. After the socially progressive impetus of the first half of the 1964-70 government, Jenkins, like most others in the government, had drifted into the familiar economistic pragmatism he had been so concerned to avoid. Having himself gone so far as to claim in a speech of 1968 that 'everything depends on making [a] success of [the] economy', he acknowledged a year later that 'our politics have of late been too much concerned with material things ${ }^{9}{ }^{98}$ 
This loss of impetus stemmed partly from a long unresolved intellectual dilemma within the party. Lawrence Black has written of the 1951-64 period that 'the left was neither as able nor willing as Conservatism to build a broad constituency of support from affluence.' This did not imply that progressives should embrace the cruder aspects of individualistic materialism. Rather, Black suggests, by engaging insufficiently with the very notion of affluence, Labour missed the opportunity to shape it on its own, more collectivist terms. ${ }^{99}$ It is an observation with which Jenkins, more than any other leading Labour figure, consistently wrestled through the 1960s. Along with other revisionists, he emphasized, after the party's third consecutive election defeat in 1959, its need to attract support from an expanding middle class. There was, he cautioned, 'a misplaced feeling that the Labour Party is a narrow class Party, representing only the working class, and it is therefore natural for those who are beginning to do well in life to move away from it'. ${ }^{100}$

By joining a meritocratic emphasis on opportunity and modernisation with egalitarian measures on social welfare, the first half of the Wilson government showed that Labour could, at its best, resolve this dilemma. Jenkins could reflect by 1967: 'The Labour Party, as the 1966 election showed conclusively, is a party with an appeal to all income and occupational groups. ${ }^{101}$ Yet, by the end of the decade, Black's dilemma was reasserting itself. The damage done to the party's economic credibility before Jenkins became Chancellor, allied to the government's loss of socially reforming impetus after devaluation were alienating middle- and working-class voters alike. The Cabinet's climb-down over the by later standards relatively modest trade union reforms favoured by Wilson, Barbara Castle and Jenkins, In Place of Strife (1969), gave a further appearance of governmental drift. The essentially twin challenge of combining prosperity for the aspirational with the progressive idealism of social reform thus remained, and would continue to vex the party for decades to come: 'If either ingredient is 
lacking', warned Jenkins in characteristically synthesising mode in 1969, 'the confluence will not be achieved, the Left will not win' ${ }^{102}$

\section{IV}

The 1970s and 1980s have been widely seen as decades of retreat for the British moderate progressive tradition. The apparent failings of Keynesian 'consensus' politics, as manifested in the economic stagflation and antagonistic industrial relations of the 1970s fuelled a resurgent Left, led by Tony Benn and then a reinvigorated New Right under Margaret Thatcher. Jackson portrays social democracy by this time as 'on the back foot', and Ellison observes its 'retreating visions. ${ }^{103}$ As Meredith notes, these challenges also exposed the previously suppressed divisions within the Labour right, with issues like Europe, rising public spending and the role of the trade unions highlighting differences between Croslandite egalitarian, Jenkinsite, and more labourist strains of opinion. ${ }^{104}$ These problems were real. However, both Jenkins' evolving 'radical centrist' ideas, and his continuing practical influence on the course of political events in these years, offer some countervailing evidence to this straightforwardly 'declinist' picture.

Jenkins continued as Shadow Chancellor, and also now party deputy leader until his resignation in 1972 over Wilson's promise of a referendum over continuing membership of the Common Market, a decision which was as much emblematic of Jenkins' wider growing frustration with Wilson's lack of imaginative new policy initiatives, and unwillingness to confront an increasingly assertive party left. Growing trade union militancy, initially under the Conservative government of Edward Heath, and, then, from 1974, under Wilson's new Labour government, seemed to Jenkins disruptive of a certain necessary equilibrium between the power of labour, managers and the state: 'Were two governments to founder on the rock of 
union intransigence it would be an appalling recognition of union omnipotence and invitation for it to be exercised still more arrogantly in the future. ${ }^{105}$ Alongside this grew a feeling that the new Labour government's public expenditure increases had little intellectual rationale behind them, or worked-out sense of where should lie the balance between public and private sectors. As Jenkins had put it in an interview of 1970: 'I certainly do not believe that the State can sit back and leave economic forces to solve all our problems. ... But equally I don't believe that the State has the answer to every problem.' 106 The issue, as ever for Jenkins, was balance, and he increasingly felt Labour had lost its balance, just as he would later see the principal vice of Thatcher's marketising zeal as that she 'lacks a sense of proportion'. ${ }^{107}$ From the summer of 1974 , Jenkins began 'for the first time to contemplate the possibility that the only way through this miasma might be outside the mould of traditional two-party politics' ${ }^{108}$

If Jenkins was now asserting more confidently and overtly his cross-class 'moderation', he remained insistent that this was an ally of, not an alternative to radicalism. Whilst his conception of the relationship between social equality and individual freedom had evolved since the 1950s, as he came by the mid-1970s to see the most immediate threat to freedom in overly powerful unions and an over-expansive state, this did not betoken an abandonment of his belief in a synthesis of these two equally important values. It was the Labour Party, he believed, which had changed more than he had, and he remained committed, as he expressed it in a 1975 television interview, to a synthesis devoted to making the country both 'more equal and more free'. ${ }^{109}$ This entailed a continuing commitment to a Keynesian interventionist approach on the economy. Writing in his Nine Men of Power (1974), Jenkins, praising Keynes' blend of ideas and practical urgency, accepted that contemporary economic problems had demonstrated that "crude Keynesianism", as it is now fashionable to describe some applications of his doctrine, has its limitations'. But he reminded readers that 'it is a great advance on crude pre-Keynesianism'. ${ }^{110}$ 
Jenkins therefore continued to defend the radically reforming credentials of his moderation, telling Robin Day in a television interview in June 1973: 'I believe that I want to see social change in this country as much as any member of the left wing. On the whole, I believe that in the last government I and people who think like me did as much for this as allegedly left wing Ministers.' ${ }^{111}$ But Jenkins was more insistent than any other leading Labour figure that being 'radical' must mean addressing the challenges of a changed British society. In his main political book of the decade, What Matters Now (1972) he called for attention to what he termed the 'new issues' of the 1970s. Labour needed to be a party 'aware of its past but more concerned with the future', one which recognised that 'many manual workers are to be found on the "haves" side of the barricade'. ${ }^{112}$ A dynamic agenda would thus address problems in a multi-layered way, beyond narrow ideological confines. Problems in the workplace, for instance, were multiple and interrelated: the boredom of mechanisation, and lack of worker representation in decision-making, and excessive strike activity. Other proposals in the book included a more individually-tailored tax and benefit system, the addressing of regional inequalities, and anti-discrimination measures. ${ }^{113}$

Above all, for Jenkins, came Europe. He wrote that 'from the late 1950s onwards a commitment to European unity, and to Britain's participation in it, became my most dominating political purpose'. ${ }^{114}$ There was truth in this, although it under-plays his focus on internal British politics. As Ludlow notes, by the time of his taking office as Commission President in 1977, his ideas on Europe were still broad-brush and Britain-focused, and he would continue as President to hanker after a return to the British political scene. ${ }^{115}$ His Europeanism was more important as a symbol of the wider changes in outlook he thought Britain needed: less bound by an outdated imperial mentality, more open and outward-looking, and willing to learn from the more progressive aspects of European economic and social policy. Engagement with Europe illustrated Jenkins' central concept of political 'constructiveness': involvement over 
withdrawal, voice over exit. He believed in 'exercising influence within Europe', rather than 'standing sullenly and self-righteously on the side-lines'. The country must abandon a 'contracting-out attitude to the world'. 116

Underpinning much of Jenkins' evolving thinking in the 1970s was a sense that the structures of British politics had lost a sense of their purpose, that 'mechanical', labourist politics was crowding out 'moral politics'. In these areas, he was influenced by two younger Labour MPs and thinkers, John Mackintosh, and, especially, David Marquand. This incorporated a recognition that an ever-expanding state alone was not a sufficient basis for creating a more progressive or egalitarian social climate, which was about outlooks as much as material redistribution. Mackintosh suggested in 1978 that Crosland's original revisionism 'did not fully appreciate that his programme was different in proposing to alter social attitudes by means of economic and institutional changes when it is by no means clear that the latter will bring about the former'. ${ }^{117}$ It meant that the institutional structure that was the Labour Party itself had to be subjected to scrutiny as to whether it any longer adequately served its purpose. By the end of the decade, Marquand, like increasingly Jenkins himself, was beginning to conclude in the negative. New ideas, wrote Marquand, 'require an open-minded and selfcritical climate, in which there are no ... sacred cows which cannot be slaughtered. In such a climate the two great myths of creed and class, the myths which hold the Labour Party together, would be dissolved'. ${ }^{118}$

For all the innovation in Jenkins' evolving thinking through the 1970s, there was a feeling of a transitional 'notes towards' a new progressive politics, in which major unaddressed issues remained. Firstly, What Matters Now illustrated what was, for a politician noted for his breadth of outlook, a curious lack of range in Jenkins' policy interests. Most striking was the omission of a chapter on either of the central public services, health and education. There had long been a noticeable pattern to Jenkins' interests, focused on the economic, foreign policy 
and home affairs areas covered by the three 'great' offices of state, to which he aspired, and there was an element of (gendered) grandeur to this prioritisation. The lack of a chapter on education, in particular, marked a change from The Labour Case. The strongly expansive educational agenda of the 1950s and 1960s had been crucial in symbolising the centre-left's claim to a 'moral politics', in which people would not merely be passive recipients of state support, but active agents in broadening their horizons and opportunities, as evident again under New Labour in the 1990s. The reduced focus on education amongst social democratic revisionists by the 1970s, also evident in Crosland's thought, was emblematic of a certain intellectual drift, in which the expansionist vision of empowering minds was replaced by a more patchwork, 'mechanical' array of materialist priorities. ${ }^{119}$

Secondly, whilst Jenkins was certainly more alive than most in the Labour Party to the growing importance of issues of social mobility and individual choice for what was an expanding middle class, appetites that the Conservatives, under first Heath and then Thatcher, were able to mobilise in their favour, he did relatively little to translate this into either a political strategy or specific policy. In a revealing passage on the subject of 'individual freedom of choice', he was notably disengaged and brief about it, dismissively asserting merely that 'large numbers of our fellow citizens lack the knowledge to calculate the advantages and disadvantages of the choices they have to make'. ${ }^{120}$ To be fair, this reflected the strength of his enduring commitment to a positive view of liberty, in which real freedom required a generously enabling state: 'the right to choose is meaningless without the power to choose'.121 But it also revealed that his engagement with the 'politics of affluence', so marked in the 1950s and 1960 s, had rather stultified.

Much of the critique of Jenkins by this time, from both the Croslandite right, and the Bennite left centres on the view that Jenkins both progressively abandoned a more firmly socialist egalitarianism, and that, partly through the seductions of an establishment lifestyle, he 
failed to stay true to his own working-class roots. Crosland felt, his biographer notes, that the Jenkinsites 'had moved so far to the Right that they disappeared from view'. ${ }^{122}$ Benn, whilst admiring Jenkins' 'great talent', thought he 'believed in maintaining the Establishment' and 'split the Labour Party which had made him what he was'. ${ }^{123}$ Certainly, there was validity to aspects of these charges. Jenkins' interest in status and hierarchy did set limits to his emotional ability to envisage a society of more fully egalitarian human relationships. He also underestimated the depth and complexity of the deprivation generated by material hardship. But, judging him by the standards of his time, and in comparison by the offered alternatives, there are two countervailing points. Firstly, he continued to maintain a position on that central question of the balance between state and market that was firmly progressive. More interventionist than 'social liberalism', whilst less so than what was now Crosland's Labour mainstream democratic socialism, Jenkins never quite adequately defined where might lie the terrain between the two. But it was always with a view significantly to spreading both resource and opportunity. Secondly, part of the ideological divergence between Jenkins, Crosland and Benn lies in the fact that their focus was simply on different things. If Jenkins did less than the latter two to sketch long-term horizons, he had the greater direct impact, and measured himself by that capacity for constructive social effect in the context of the moment.

Jenkins, by now in his fifties, thus mixed adventurous re-thinking with hesitant intellectual inertia in the 1970s, moving steadily away from the labourist culture into which he had been born, but with many backwards glances, telling his advisor, Anthony Lester in 1974: 'The Labour Party would collapse like a house of cards if it were effectively challenged. The trouble is that I am too rooted in the party by family and tradition to make the attempt'. ${ }^{124} \mathrm{He}$ slipped in the Cabinet rankings following his 1972 resignation, and the party's re-election in 1974 brought only a return to the Home Office. When the election to succeed Wilson finally arrived in 1976, he came third, and, his allegiance to Labour fading, he left for the European 
Commission. If the above is indicative of a marginalisation of the political centrist in the $1970 \mathrm{~s}$, in other ways Jenkins highlights the under-estimated resilience of the British moderate tradition in these years. He remained one of the country's most important political figures, and his influence increasingly extended beyond Labour. Given the rebellion of Conservative antiMarketeer MPs, his leading of 69 Labour MPs to defy a three-line whip to vote in favour of Heath's October 1971 European Communities Bill was of decisive importance. ${ }^{125}$ Then, in 1975, he was president of the successful referendum campaign to remain. This vote could be taken as further evidence of a robust centre against anti-Marketeers on both right and left.

Alongside this, undertaking, again, 'the peculiar balance-striking challenges of being Home Secretary', Jenkins continued to pursue a distinctive synthesis, combining 'the maintenance of the proper authority of the state', against both the IRA (through the introduction of the Prevention of Terrorism Act), and extra-legal trade union activity, with again, as he saw it, 'in no way incompatible ... legislation on the rights of individuals', notably the Sex Discrimination (1975) and Race Relations Acts (1976). ${ }^{126}$ More widely, for all Jenkins' dissatisfaction with Wilson's and Callaghan's labourism, he was able consistently to join with them to ensure that at no point was the left seriously likely to gain control of the Cabinet.

More broadly, although Jenkins was edging towards leading a reconfiguration of British party politics, he retained a consistently hardy optimism in the underlying good political sense of the people, despite the decade's turbulence. His view was that the modish intellectual penchant for disillusionment was both unhistorical, and, because not constructive, dangerous. In an appraisal of world trends in a speech in Pennsylvania in 1973, he insisted that he did not 'believe that we should accept or be depressed by what is one of the most widespread ... beliefs today: the dismal conviction that the world is getting worse.' Instead, 'I do not believe that the conditions of this country and of most countries have consistently worsened. There is on the whole more tolerance, less cruelty, more humanity, even more happiness' ${ }^{127}$ Reflecting on 
the 1975 referendum campaign, during which he had addressed many large public meetings, Jenkins, noting the obvious dangers of the 'appeals of chauvinism, populism and the desire to cock a snook', was pleased to discover that 'it was always the high arguments, the broad discussion of the country's future orientation, ... which most captured the attention and fired the imagination of audiences'. ${ }^{128}$ It is a perhaps pertinent reminder of the insights of perspective and resilient optimism in hard political times.

'The brief history of the British Social Democratic Party is one of failure'. ${ }^{129}$ So conclude the authors of the leading study of the new political party which Jenkins had done more than anyone to create, and represented the culmination of his intellectual and political journey. Jenkins himself, they argue, was both an ineffectual leader of the new party, and, intellectually, 'failed to find a coherent theme for the Alliance's policies'. ${ }^{130}$ Certainly, the Alliance did fail in its immediate objective of breaking the mould of class politics, and becoming genuine contenders for government, winning just 23 seats at the 1983 election. But setting aside this, in retrospect, improbably high bar, its significance, and with it Jenkins' own contribution in this final part of his career, was greater than the above appraisal suggests.

The SDP's agenda, and with it, because Jenkins shared much ideological ground with Liberal leader David Steel, the wider platform of the Alliance, stemmed logically from Jenkins' synthesising politics of the 1950s and 1960s. But it required the further educative political experience of the 1970s to generate the more self-confidently cross-ideological outlook which defined the SDP. It was, therefore, as Jenkins put it in 1982, 'a new party seeking a new synthesis', built on ideas of its times, not simply one wedded, in the oft-cited phrase attributed to the sociologist Ralf Dahrendorf, to 'a better yesterday'. ${ }^{131}$ 
The Alliance's agenda represented the final refinement of Jenkins' belief in reconciling perceived polarities. There would be an offer for both the deprived and the affluent: 'we want the support of all those whose aim in life is to get on, not hold on to what they've got' Jenkins claimed in 1981, 'but who believe that in getting on, they are ... benefiting the community as a whole'. ${ }^{132}$ On economic policy, tackling unemployment, Jenkins noted, 'requires a stimulus from the Government, which this Government will not give. But the stimulus will not work unless it gets a confident response from private business. ... The Alliance would secure both the stimulus and the response.' ${ }^{133}$ There should not be endless disruptive re-nationalisations or privatisations. We need to 'treat public and private industry with equal respect'. ${ }^{134}$ There would be encouragement for constructive trade unionism, but also the accountability of union leaders to their members, and to society. ${ }^{135}$ Jenkins' (as well as the Liberals') longstanding democratising instincts were also evident in the strong support for proportional representation, and political and industrial decentralisation.

Declinist narratives of British social democracy have suggested that Jenkins and the SDP symbolised that 'the old [Labour revisionist] demands for equality were replaced with new demands for freedom', meaning 'degenerating into a politics of moderation' ${ }^{136}$ Some on the Labour right who remained with Labour, like the egalitarian Roy Hattersley, had long worried about the dilution of equality he perceived in Jenkins' 'drift to the political centre'. ${ }^{137}$ But Jenkins saw himself as necessarily refreshing, for a more individually aspirational age, his longstanding synthesis between greater equity and freedom. His Dimbleby Lecture call was explicitly for a 'radical centre', and he remained a firm believer in Keynesian intervention, well-funded public services, and the wider distribution of opportunity. ${ }^{138}$

If anything, it was the individual 'freedom', or aspirational part of the synthesis which Jenkins, and the early Alliance under-developed. As in the 1970s, Jenkins exhibited a recognition of the importance of rising appetites for accountability and choice - 'we want to 
improve the lot of patients and pupils, not treat them as pawns in an out-of-date class war' but without wholeheartedly embracing this, or translating it into policy. ${ }^{139}$ Alliance manifesto support for home ownership was half-hearted, and its genuine focus on wide-ranging decentralisation was numbed by the limiting of this to the provision of more power for local authorities, as distinct from consumers, workers, or parents. ${ }^{140}$ Here is further striking evidence that the 1980s' centre-left, even, as with Jenkins, in its most adaptive, self-critically revisionist form, continued to struggle in coming fully to terms with a more demanding, socially mobile and expectant citizenry.

This insufficient sense of a 'modern' policy appeal was well-recognized by Jenkins' successor as SDP leader from 1983, the youthful, dynamic David Owen, whose development of the idea of a social market - to 'simultaneously break right on the market and left on social policy', as he put it - entailed a more willing, and at times innovative engagement with the changing society. ${ }^{141}$ But here Jenkins' longstanding concept of proportion seems an especially illuminating prism through which to view the later SDP. If Jenkins had in some ways remained too conventionally statist, Owen seemed to lose that ever delicate balance too far the other way, in his lauding of both the abrasive leadership style of Thatcher, and the market. As Dean Blackburn has argued, whilst promising a measured synthesis, 'Owen glossed over ... how to pair up enthusiasm for the free market with concern for fellowship'. ${ }^{142}$ It was a final note to Jenkins about the high bar he had set by his pursuit of the elusive ideological golden mean.

Jenkins also exhibited shortcomings of leadership. By then in his early sixties, he lacked the pithy soundbite for television. Politics had become too much 'like ... a game of snap', as he ruefully described it. ${ }^{143}$ His approach to the 1982 Falklands War was too hedged with qualifications for a party leader on such a major subject, suggesting that, for all his leadership qualities, Jenkins did not quite possess the intensity of appetite, range of policy interest, or sheer political hide for the Premiership. Wilson's complaint to him that, in his 
elegant aloofness, he failed to realise how much time a political leader needs to spend 'wading in shit', contained a kernel of truth. ${ }^{144}$ This hinted at Jenkins' own musing, part insider, part rebel, on 'the question of how much I was truly at ease with power'. ${ }^{145}$ That is not to underestimate his very real desire to be Prime Minister. But, as he had shown by his resignation over Europe, when at the peak of his potential to be Labour leader, he would not sacrifice everything for it. As Shirley Williams records, 'he took a long view and a large view, which was why his personal ambition was always tempered by a certain detachment'. ${ }^{146}$

Yet, 'failure' is far from an adequate word for either the Alliance, or this last political incarnation of Jenkins. If the Alliance demonstrated a centre unable to replace class politics, the strength of the centre as a constraint on the 'extremes' in the 1980s, and the wider defensive resilience of the post-war settlement against Thatcherism have been under-estimated. The 1983 election result marked the establishment of a consistently more strongly supported third force in British politics, formalised by the creation of the Liberal Democrats in 1988. This operated as a persistent moderating reminder to both the larger parties throughout the decade, most starkly Labour, that there existed a credible alternative receptacle for centre-left or centre-right voters. Historians are now increasingly modifying perceptions of a hegemonic Thatcherism in the 1980s, noting the countervailing moderating influences in her Cabinet, and amongst the electorate, and that the more social democratic values of the 1945-79 period did not simply evaporate on the day of her election. ${ }^{147}$ This is strikingly evident in the sphere of social liberalisation, where in almost all respects, despite Thatcher's inclination to traditional values, Jenkins' 1960s' reforms remained intact.

Furthermore, the revitalisation of the centre-right and centre-left traditions within the Conservative and Labour parties after Thatcher's fall in 1990 could be seen as evidence that, in his critique of the polarised politics of the 1970s and 1980s, Jenkins was ahead of his time. New Labour, in its early, most progressively dynamic form, echoed many of the ideological 
syntheses Jenkins had formulated, above all his quest to join social conscience with individual aspiration, a proposed fusion which continues to speak to the political challenges of the present. Today, amidst the renewed political divisions surrounding the Brexit vote, and a growing gap between the two main parties, ideas of a new progressive centrist party are once again to the fore, given initial concrete form, in February 2019, by the creation of the Independent Group.

Jenkins can also claim greater consistency in his ideological position than other leading 'centrists' of his time. He was clear that Owen, after 1983, took the SDP too far rightwards. It now seemed rather paradoxical, he reflected in 1985, that he (Jenkins) had initially been 'considered to be the most right-wing of the Gang of Four', noting that 'I always saw the SDP as being a radical alternative to the Tories, a left-of-centre party if the old hemicycle terms are to be used'. ${ }^{148}$ Writing in the early years of John Major's Premiership, with that sense of historical proportion uniquely his, Jenkins reflected that 'levels of taxation on the prosperous, having been too high for many years (including my own period at the Treasury), are now too low for the provision of decent public services'. ${ }^{149}$

Jenkins was a firm admirer of the early Tony Blair, seeing him as 'the most exciting Labour choice since the election of Hugh Gaitskell', a man who could forge a progressive agenda with broad national appeal, and heal the divide between Labour and his own Liberal Democrats. But he also increasingly worried about Blair's tendency to take things too far, noting the danger of a weddedness to marketisation. ${ }^{150}$ By the end of his life, in the context of the country's apparent move towards war with Iraq, and in what was to prove his final speech in the Lords, on 24 September 2002, he warned that Blair had now become 'a little too Manichaean for my perhaps now jaded taste, seeing matters in stark terms of good and evil'. ${ }^{151}$ In comparing the two men, Blair achieved a worked-out 'third way' and a reinvigorated 'moral politics', built around reinvestment in public services, a synthesis of responsibilities and opportunities, and a particular, dynamic prioritisation of education, which chimed with the 
times to a degree Jenkins never managed. He also possessed a democratic, emotionallyconnected communicational style from which Jenkins was far removed. On the other hand, Jenkins was a more grounded, 'rooted' politician, more consistent in the broadly left-of-centre political space he occupied, and less inclined to rightwards ideological or governmental lurches, emanating from the seductions of either personal power, or uncritical affection for the 'newness' of economic 'modernity'. In this sense, he outdid Blair in that measured political 'balance' which was the distinguishing mark of both figures in their prime.

Hinting again at the charge against Jenkins' supposedly elitist disconnect with the people, Crewe and King write that 'the niceties of Alliance politics were far removed from the world of the apprentice garage mechanic in Bolton or the trainee hairdresser in Southend' ${ }^{152}$ Jenkins undoubtedly over-estimated the readiness of voters in the early 1980 s to break with class politics. But in this, the final iteration of his exploration of the relationship between politics and the voters, the people's political importance was foregrounded more directly than ever. Firstly, popular support for the Alliance was far from insignificant. From October 1981 to March 1982, it consistently topped the opinion polls, in one Gallup poll of December 1981 scoring fifty-one per cent, the highest figure for any party over the $1979-83$ parliament. ${ }^{153}$ In Jenkins' victory in the 1982 Glasgow Hillhead by-election, he achieved a Gladstonian-style synthesis, delivering lofty ideals to packed public meetings. Williams garnered even more public affection in her victory in Crosby. The Alliance message of cross-class constructiveness, for all its ultimately brief ascendancy, spoke to a genuine, albeit inchoate yearning for something different.

Secondly, the Alliance represented the culmination of Jenkins' longstanding pursuit of a 'moral politics', one in which popular idealism and engagement mattered as much as the changing of laws or economic policy through Whitehall. 'We need more than a change of economic direction', he insisted in 1982. Also required was a fundamental reform of 'the 
character of our politics', and 'a transformation of our social attitudes', replacing 'class selfishness and social division with a sense of common purpose'. ${ }^{154}$ The Alliance's emphasis on participation and decentralisation constituted a critique of the perceived over-focus of the contemporary left and right on a debate about economic systems, rather than the actual lived experiences of real people within those systems. But it was also a critique of some of the topdown excesses of the post-war settlement. The emphasis on 'system changes', as Shirley Williams put it in her aptly titled Politics Is For People (1981), had neglected 'the people ..., the human factor'. ${ }^{155}$ For Jenkins, similarly, 'the pursuit of bigness for bigness sake ... under both the old parties has made politics and industry too remote from the people'. ${ }^{156}$ Again here, Alliance thinking innovatively foreshadowed future participatory agendas, ranging from Major's Citizens' Charter, through Blair's pursuit of devolution and call for a revived sense of 'community', to David Cameron's notion of a 'big society'.

Finally, the Alliance's advocacy of a greater role for the citizenry also reflected an underlying confidence in the people's capacities. This was not naïve utopianism. Jenkins' distinctively nuanced view of the people's mix of conservatism and idealism remained. 'Innovation that is not adapted to the ways and traditions of a society is doomed to frustration and disillusion', he cautioned in a speech of June 1981. 'That is a valuable lesson for all of us in politics who claim to be radical. ${ }^{157}$ Yet, as in earlier times, the sobriety makes the coexisting optimism doubly worthy of attention. The electorate's 'aspirations', Jenkins suggested in his Dimbleby Lecture, 'not on every issue, but in essential direction, pull far more towards the centre than towards the extremes'. ${ }^{158}$ Britain was an 'essentially moderate country'.159 'We have not', he insisted in 1981, 'lost the sense of community and public spirit which has been such a strength to us in the past'. ${ }^{160}$ The Alliance thus existed to trust and channel this popular spirit, to 'ensure that the good sense of the voters is allowed to illuminate the corridors of Westminster and Whitehall'. ${ }^{161}$ This was Jenkins' most persistent and, given his perceived 
status as archetypal elitist, under-recognised insight: political progress must, and ultimately could rely on the British people themselves.

Capturing that familiar sense of Roy Jenkins as an Asquithian figure, remote from the more thrusting political challenges of the present more democratic, egalitarian and populist age, David Marquand has written recently of his erstwhile hero's 'broken legacy'. Jenkins was, he now contends, 'a would-be establishment Whig, with occasional forays into radicalism', whose ideas 'never led him beyond the comfort zone of the bien pensant intelligentsia'. Today, 'in the harsh climate of the twenty-first century, bien pensant liberalism is no longer enough' ${ }^{162}$ Whilst this powerfully illuminates Jenkins' undoubted shortcomings, it under-plays both the extent of his significance, and the continuing relevance of his insights. Present populism tends simultaneously to flatter the populace, and demonise (sections of) it. Jenkins provides a more layered, nuanced outlook on the people, one which recognises in them an under-estimated political constructiveness, whilst challenging them further to raise their sights. In this sense, he echoes Jon Lawrence's portrayal of that enduring dual wish of the reformer, 'both to speak for the people, and to change them' ${ }^{163}$ Above all, he had confidence in the citizenry to respond positively in apparently bleak times.

Resting on this underlying confidence in the British national character, Jenkins' blend of 'radical moderation' also offers hope that new, more positive and progressive political visions may emerge from the presently polarised British ideological and party divide. The ambitious syntheses he commended, and helped further as a politician, yet was unable to see to full fruition, arguably remain pertinent. How to address poverty and advance aspiration? How to blend the finest elements in both the social democratic and liberal traditions? Above all, perhaps, Jenkins rode that perennially fine balance on the cusp between idealism and 
realism. At some moments he seemed to make too much concession to orthodoxy, and social pretension. At others, in contrast, his ideals appeared too far ahead of his time. Often, however, his radical and moderating, idealistic and practical instincts came together in a distinctively constructive and humane harmony, enabling the vision of what might be to become what is.

\section{$\underline{\text { Notes }}$}

1 J. Campbell, Roy Jenkins. A Well-Rounded Life (London, 2014). See also his shorter J. Campbell, Roy Jenkins (London, 1983).

${ }^{2}$ A. Adonis \& K. Thomas (eds), Roy Jenkins: A Retrospective (Oxford, 2004); G. Radice, Friends and Rivals: Crosland, Jenkins and Healey (London, 2002); N.P. Ludlow, Roy Jenkins and The European Commission Presidency, 1976-1980 (Basingstoke, 2016).

${ }^{3}$ I. Crewe \& A. King, SDP (Oxford, 1995). See also P. Lee Sykes, Losing From The Inside: The Cost of Conflict in The British Social Democratic Party (London, 1990), which also explains perceived failure.

${ }^{4}$ B. Jackson, Equality and The British Left: A Study in Progressive Political Thought, 1900-64 (Manchester, 2007). Jenkins also features negatively in G. Foote, The Labour Party's Political Thought, $3^{\text {rd }}$ edn. (London, 1997), pp. $246 \& 254$. Though there is valuable analysis in S. Meredith, Labours Old and New: The Parliamentary Right of The British Labour Party 1970-79 
and The Roots of New Labour (Manchester, 2008); S. Haseler, The Gaitskellites: Revisionism in The British Labour Party 1951-64 (London, 1969); N. Ellison, Egalitarian Thought and Labour Politics: Retreating Visions (London, 1994).

${ }^{5}$ See, for instance, G. O'Hara \& H. Parr (eds), 'The Wilson governments $1964-70$ reconsidered', Contemporary British History, special issue, 20/3 (2006), pp. 295-489; B. Pimlott, Harold Wilson (London, 1992); A. Crines \& K. Hickson, Harold Wilson: The Unprincipled Prime Minister? (London, 2016); P. Diamond, The Crosland Legacy (Bristol, 2016); K. Jefferys, Anthony Crosland (London, 1999); J. Nuttall, 'The Labour party and the Improvement of minds: the case of Tony Crosland', The Historical Journal, 46 (2003), pp. 133-53.

${ }^{6}$ Jefferys, Crosland, pp. 193-6.

${ }^{7}$ R. Jenkins, The Labour Case (Harmondsworth, 1959), p. 7; R. Jenkins, A Life at The Centre (London, 1991), p. 617.

${ }^{8}$ On the neglect of the ideological 'centre', see B. Harrison, 'The centrist theme in modern British politics', in his Peaceable Kingdom: Stability and Change In Modern Britain (Oxford, 1982); \& A. Marwick, 'Middle opinion in the thirties: planning, progress and political "agreement", English Historical Review, 79 (1964).

${ }^{9}$ As in Jackson, Equality or Ellison, Egalitarian.

10 M. Freeden, Liberalism Divided: A Study In British Political Thought 1914-1939 (Oxford, 1986), p. 371 . For some attention to themes of centrism and cross-party cooperation, see G.R. Searle, Country Before Party: Coalition and The Idea of National Government in Modern Britain, 1885-1987 (London, 1995); K. Middlemas, Power, Competition and The State, I: Britain in Search of Balance, 1940-61 (London, 1986).

${ }^{11}$ Harrison, 'Centrist', p. 375. See also S. Bastow \& J. Martin, Third Way Discourse: European Ideologies in the Twentieth Century (Edinburgh, 2003), p. 1. 
${ }^{12}$ Bodleian Library, Oxford, Macmillan Papers, dep. c.740/ 13-14, speech, 22 Jan. 1957.

${ }^{13}$ British Library of Political and Economic Science, London, Durbin Papers, 1/3, 21, lecture notes, 1937.

14 Jenkins, Centre.

${ }^{15}$ A. Hindmoor, What's Left Now?: The History and Future of Social Democracy (Oxford, 2018);

S. Brooke, 'Living in "new times": historicizing 1980s Britain', History Compass, 12 (2014), pp. 20-32; E. Robinson, C. Schofield, F. Sutcliffe-Braithwaite \& N. Tomlinson, 'Telling stories about post-war Britain: popular individualism and the "crisis" of the 1970s', Twentieth Century British History, 28 (2017), p. 268.

${ }^{16}$ Jenkins, Centre, p. 621.

${ }^{17}$ Meredith, Labours, p. 180.

${ }^{18}$ L. Black, The Political Culture of The Left in Affluent Britain, 1951-64 (Basingstoke, 2003).

19 J. Carey, The Intellectuals and The Masses (London, 1992), pp. 21-2.

${ }^{20}$ D. Marquand, The Unprincipled Society (London, 1988), p. 20.

${ }^{21}$ M. Jarvis, Conservative Governments, Morality and Social Change in Affluent Britain, 19571964 (Manchester, 2005), p. 161; Black, Affluent.

${ }^{22}$ R. Eatwell \& M. Goodwin, National Populism: The Revolt Against Liberal Democracy (London, 2018), p. xxi.

${ }^{23}$ Respectively, K.O Morgan, The Independent, 30 Sept. 2002; Foote, Labour, p. 243; Crewe \& King, SDP, p. 151.

${ }^{24}$ D. Marquand, “'The Welsh wrecker"', in Adonis \& Thomas (eds.), Jenkins, p. 111; see also D. Marquand, The Progressive Dilemma. From Lloyd George To Blair, $2^{\text {nd }}$ edn. (London, 1999). 25 Jenkins, Centre, p. 620.

${ }^{26}$ P. Clarke, Liberals and Social Democrats (Cambridge, 1978), pp. 4-5 \& 243. 
${ }^{27}$ S. Fielding, P. Thompson and N. Tiratsoo, 'England Arise!': The Labour Party and Popular Politics in 1940s Britain (Manchester, 1995), p. 218; S. Fielding, The Labour Governments 1964-70: vol. 1: Labour and Cultural Change (Manchester, 2003).

28 L. Black, Redefining British Politics: Culture, Consumerism and Participation, 1954-70 (Basingstoke, 2010), p. 210.

29 J. Nuttall, Psychological Socialism: The Labour Party and Qualities of Mind and Character, 1931 To The Present (Manchester, 2006); R. Toye, 'Keynes, liberalism and "the emancipation of the mind", English Historical Review, 130 (2015), pp. 1183 \& 1191.

30 J. Lawrence, Electing Our Masters: The Hustings in British Politics From Hogarth to Blair (Oxford, 2009), pp. $96 \& 128$.

${ }^{31}$ R. Jenkins, Pursuit of Progress: A Critical Analysis of The Achievement and Prospect of The Labour Party (London, 1953), p. 173.

${ }^{32}$ Macmillan Papers, dep. c.740/ 68, speech to The English Speaking Union, 1957.

${ }^{33}$ C.A.R. Crosland, The Future of Socialism (London, 1956), p. 247.

${ }^{34}$ Ludlow, European, pp. 20-21.

35 Bodleian Library, Oxford, Jenkins Papers, 337, speech to Stechford selection conference, 1950.

${ }^{36}$ Jenkins, Progress, p. 174.

37 Jackson, Equality, pp. 170-71.

${ }^{38}$ R. Jenkins, 'Equality, in R.H.S. Crossman (Ed.), New Fabian Essays (London, 1952), p. 85. $39 \mathrm{lbid}$.

40 Jenkins Papers, 336, speech, Banbury, early 1945.

${ }^{41}$ Ibid., 337, speech', 'Socialism and the individual', Birmingham Fabian Society, Oct. 1956.

42 Jenkins, Labour, pp. 9 \& 57-8. 
${ }^{43}$ Jenkins, Centre, p. 85.

44 Jenkins Papers, 337, 'The case against Bevanism', broadcast, 31 Oct. 1952.

45 Jenkins, Progress, p. 184.

46 Ibid., p. 68.

47 Jenkins Papers, 337, 'The future of the Labour party', 1959.

48 Ibid., 303, television interview with Llew Gardner, 30 Jan. 1975.

49 Ibid., 337, 'The case against Bevanism', broadcast, 31 Oct. 1952.

${ }^{50}$ R. Jenkins, Asquith (London, 1964), pp. 195 \& 279.

51 Jenkins Papers, 344, speech, University of New York, 6 Jan. 1983.

52 Ibid., 344, notes, London, 4 Dec. 1950.

${ }^{53}$ S. Williams, Climbing The Bookshelves (London, 2010), p. 269.

54 Jenkins, Centre, p. 619.

55 Jenkins Papers, 337, speech to Stechford selection conference, 1950.

${ }^{56}$ Crosland, Future, pp. 521-2; Jenkins, Labour, p. 146.

57 Jenkins, Progress, pp. 181-2.

58 Ibid., p. 182.

59 lbid.

60 Jenkins Papers, 294, speech, 'The Labour Party in the Seventies', Blackpool, 29 Sept. 1970.

61 Jenkins, Progress, p. 151.

62 Jenkins Papers, 337, 'Next steps in Socialism', 6 Dec. 1950.

63 Ibid., 337, 'Eve of the Poll', 1951.

64 Ibid., 337, 'Eve of Poll, notes, 22 Feb. 1950.

${ }^{65}$ Ibid., 292, speech to United States Pilgrims, 8 Apr. 1968.

${ }^{66}$ Ibid., 303, speech to Birmingham Fabians, 18 Jan. 1974. 
${ }^{67}$ D.L. LeMahieu, A Culture For Democracy: Mass Communication and the Cultivated Mind in Britain Between The Wars (Oxford, 1998), p. 4.

68 Jenkins, Labour, pp. 54-5.

${ }^{69}$ Jenkins Papers, 337, speech, 'Socialism and the individual', Birmingham Fabian Society, Oct. 1956.

70 Ibid., 294, speech, 'The Labour Party in the Seventies', Blackpool, 29 Sept. 1970.

71 Jenkins, Progress, p. 136.

72 Jenkins Papers, 291, speech to annual conference of London Labour Party, 13 May 1967.

${ }^{73}$ Ibid., 303, television interview with Llew Gardner, 30 Jan. 1975.

${ }^{74}$ For different perspectives on this debate, see Fielding et al., 'England Arise!'; R. McKibbin, Parties and People: England, 1914-1951; J. Lawrence, 'The transformation of British public politics after the first world war', Past and Present, 190 (Feb. 2006), pp. 215-16.

75 Jenkins, Progress, p. 3.

${ }^{76}$ R. Crossman, diary entry, 16 Apr. 1968, in The Diaries of A Cabinet Minister, II (London, 1976), p. 784.

77 D. Owen, Time To Declare (London, 1992), pp. 558 \& 566.

78 Jenkins, Centre, p. 617.

${ }^{79}$ D. Marquand, 'The broken legacy of Roy Jenkins', New Statesman, 26 March 2014.

${ }^{80}$ R. McIntosh, 'Balliol', in Adonis \& Thomas (eds), Jenkins, p. 17; Campbell, Jenkins, pp. 330$31 \& 734$.

${ }^{81}$ Marquand, '“Welsh wrecker”', p. 124; Jenkins, Centre, p. 352.

${ }^{82}$ A. Lester, 'The Home Office again', \& Bill Rodgers, 'SDP', both in Adonis \& Thomas (eds), Jenkins, p. 151 \& 217-8.

${ }^{83}$ D. Cannadine, Class in Britain (London, 2000), p. 150. 
${ }^{84}$ Jenkins Papers, 294, speech, 'The Labour Party in the Seventies', Blackpool, 29 Sept. 1970.

85 Jenkins, Centre, pp. $155 \& 190$.

86 Ibid., p. 190.

87 Ibid., p. 218.

${ }^{88}$ R. Crossman, diary entry, 16 Apr. 1968, in The Diaries of A Cabinet Minister, II (London, 1976), p. 784.

89 Jenkins Papers, 291, speech to annual conference of London Labour Party, 13 May 1967.

90 Ibid.

${ }^{91}$ Owen, Time, p. 110.

92 H. Wilson, The Labour Government 1964-70 (Harmondsworth, 1974), pp. 249 \& 608.

93 Jenkins Papers, 292, speech to Oxford Labour Club, 31 Oct. 1969.

94 Ibid.

95 Ibid., speech to United States Pilgrims, 8 Apr. 1968; budget speech, 19 March 1968.

${ }^{96}$ B. Castle, Fighting All The Way (London, 1994), p. 426; Jenkins, Centre, p. 292

97 Jenkins Papers, 319, interview, n/d, 1970.

98 Ibid., 292, speech to Stockport GMC, 1968; speech to Abingdon CLP, 19 July 1969.

${ }^{99}$ Black, Affluent, pp. 189-90.

100 Jenkins Papers, 337, Fabian Society Lecture, 4 Nov. 1959.

101 Ibid., 291, speech to annual conference of London Labour Party, 13 May 1967.

102 Ibid., 292, speech to Oxford Labour Club, 31 Oct. 1969.

${ }^{103}$ See respectively Jackson, Equality, p. 224; Ellison, Egalitarian.

104 Meredith, Labours, p. 173.

105 Jenkins, Centre, p. 424.

106 Jenkins Papers, 293, interview, n/d, 1970. 
107 Ibid., 319, speech to SDP meeting, 4 Oct. 1982.

108 Jenkins, Centre, p. 388.

109 Jenkins Papers, 303, television interview, People and Politics, 30 Jan. 1975.

${ }^{110}$ R. Jenkins, Nine Men of Power (London, 1974), p. 21.

111 Jenkins Papers, 301, TV interview with Robin Day, 1 June 1973.

${ }^{112}$ R. Jenkins, What Matters Now (London, 1972), pp. 117 \& 122.

113 Ibid., pp. 10-12, 81 \& 88-9.

${ }^{114}$ R. Jenkins, European Diary: 1977-1981 (London, 1989), p. 1.

115 Ludlow, European, p. 47.

${ }^{116}$ R. Jenkins, 'From London to Rome', Encounter (August 1961), reproduced in his Essays and Speeches (London, 1967), pp. 122-3.

117 J. Mackintosh, 'Has social democracy failed in Britain?', The Political Quarterly, 49 (1978),

p. 266.

${ }^{118}$ D. Marquand, 'Inquest on a movement: Labour's defeat and its consequences', Encounter, 53 (July 1979), p. 11.

119 On this 'moral-mechanical' divide, see Nuttall, Psychological, pp. 119-21. For Crosland's thinking, see A. Crosland, Socialism Now (London, 1974).

120 Jenkins, Matters, p. 15.

121 Ibid.

122 S. Crosland, Tony Crosland (London, 1983), p. 222.

${ }^{123}$ T. Benn, diary entry, 27 March 2003, in his More Time For Politics: Diaries, 2001-2007

(London, 2007), p. 108.

${ }^{124}$ Lester, 'Home Office', p. 152.

${ }^{125}$ Ludlow, European, p. 20. 
126 Jenkins, Centre, pp. $376 \& 382$.

127 Jenkins Papers, 301, address, Pennsylvania Commencement, 21 May 1973.

128 Jenkins, Centre, p. 417.

${ }^{129}$ Crewe \& King, SDP, p. 455.

130 Ibid., pp. 459-60.

131 Jenkins Papers, 343, speech, SDP Consultative Assembly, Derby, 13 Oct. 1982. The precise origin of the 'better yesterday' comment is unknown.

132 Ibid., 318, speech, London, 24 June 1981.

133 Ibid., 322, speech, Paisley, 14 Feb. 1986.

134 Ibid., 319, speech, Hillhead, 14 Jan. 1982.

135 Working Together For Britain: 1983 Alliance Election Manifesto.

${ }^{136}$ Foote, Labour, pp. 246 \& 254.

${ }^{137}$ R. Hattersley, Who Goes Home? (London, 1995), p. 108.

${ }^{138}$ R. Jenkins, Home Thoughts From Abroad (London, 1979), p. 17.

139 Jenkins Papers, 344, 'Ask the Alliance' meeting, Glasgow, 16 May 1983.

140 Working Together For Britain.

${ }^{141}$ Owen, Time, p. 599.

142 D. Blackburn, 'Facing the future? David Owen and social democracy in the 1980s and beyond', Parliamentary Affairs, 64/4 (2011), p. 644.

143 Jenkins, Centre, p. 565.

144 Ibid., p. 337.

145 Ibid., p. 622.

${ }^{146}$ Williams, Bookshelves, p. 268.

147 Hindmoor, Left; Brooke, ' "New times”; Robinson et al, 'Popular individualism'. 
${ }^{148}$ R. Jenkins, Partnership of Principle: Writings and Speeches on The Making of the Alliance (London, 1985), p. 6.

149 Jenkins, Centre, p. 617.

150 The Times, 23 July 1994.

${ }^{151}$ R. Jenkins, speech, 24 Sept. 2002, House of Lords, vol. 638, cols 892-4.

${ }^{152}$ Crewe \& King, SDP, pp. 460 \& 464.

153 Ibid., pp. 133 \& 144.

154 Jenkins Papers, 343, speech, SDP Consultative Assembly, Derby, 13 Oct. 1982.

${ }^{155}$ S. Williams, Politics is For People (Middlesex, 1981), p. 164.

156 Jenkins Papers, 322, speech, Durham, 8 Nov. 1985.

157 Ibid., 318, address, London, 16 June 1981.

158 Jenkins, Thoughts, p. 10.

159 Jenkins Papers, 344, 'Ask the Alliance' meeting, Glasgow, 16 May 1983.

160 Ibid., 318, speech, London, 24 June 1981.

161 Working Together For Britain.

162 Marquand, 'Broken legacy'.

163 J. Lawrence, Speaking For The People: Party, Language and Popular Politics in England, 1867-1914 (Cambridge, 1998), p. 263. 